\title{
The behaviour of housed dairy cattle with and without pasture access: a review
}

\author{
by Charlton, G.L. and Rutter S.M.
}

Copyright, Publisher and Additional Information: This is the author accepted manuscript. The final published version (version of record) is available online via Elsevier

Please refer to any applicable terms of use of the publisher.

DOI: https://doi.org/10.1016/j.applanim.2017.05.015

Harper Adams

University

Charlton, G.L. and Rutter S.M. 2017. The behaviour of housed dairy cattle with and without pasture access: a review. Applied Animal Behaviour Science. 


\section{The behaviour of housed dairy cattle with and without pasture access: a review}

2 Gemma L. Charlton ${ }^{1}$ and S. Mark Rutter

3 Harper Adams University, Edgmond, Newport, Shropshire, TF10 8NB, United Kingdom

$4 \quad{ }^{1}$ Corresponding author: Gemma L. Charlton; Telephone number: +44 (0)1952 815066; Fax number:

$5 \quad+44$ (0)1952 814783; E-mail address: gcharlton@harper-adams.ac.uk

6 ABSTRACT

7 With more dairy cows being housed indoors, for at least part of the year, it is important to understand

8 how housing impacts on 'normal behaviour' and the implications for cow welfare. For cows on

9 pasture, nutritional requirements and climatic conditions are the major concerns, whilst indoor housing systems can restrict natural behaviours and reduce health as incidences of lameness and mastitis increase. When given a choice to be at pasture or in cubicle housing, studies have shown that time of day, season, and where feed is provided can influence preference. Previous experience also had a big effect on pasture preference: the longer calves/heifers/cows were reared without experience of pasture the stronger their preference for housing. The ontogeny of grazing also requires pasture experience i.e. the instinctive foraging behaviour of calves is to suckle and they have to learn through experience how to graze. These results raise the question: if cattle are to be housed for part of the year, would it be better to house them continuously? Other results would suggest not, as there are clear production, health and welfare benefits to pasture access. Cows at pasture had lower levels of lameness and mastitis, and cows with free access to pasture and indoor housing also produced more milk than those continuously housed. Approximately half of this extra milk was attributed to grass intake, and increased lying, improved comfort and/or lower stress probably accounted for the rest. Although incorporating free access between housing and pasture is difficult on many farms, it is postulated that developments in precision livestock farming offer the potential to provide a technological solution to this problem. These research findings could be used as the basis to design novel, adaptive housing that responds to cow behaviour. The aim would be to incorporate the best aspects of pasture with the best aspects of housing to provide an environment that meets the needs of the cows all year around. 
Keywords: Pasture, indoor housing, dairy cattle, behaviour, precision livestock farming, technologies

\section{Introduction}

Public concern for the welfare of intensively farmed animals is increasing (Prickett et al., 2010). Consumers have a strong preference for livestock to be reared in natural environments, such as pasture access for farm animals (Cardoso et al., 2016; Vanhonacker et al., 2008), and it has been assumed for many years that natural or extensive husbandry systems provide better welfare (Webster, 1994). However, in recent years, intensification of the dairy industry has increased. In many European countries and in the United States whilst the number of dairy farms has decreased, this has been offset by increased herd sizes (Barkema et al., 2015) and increased average yield per cow (DairyCo, 2016; EC, 2015). These yield increases have led to many cattle being housed indoors, for at least the winter months, if not all year around; with straw yards and cubicle housing the most common indoor housing systems (Haskell et al., 2007).

For cattle, pasture is a natural environment, allowing them to express normal behaviours. It can provide ample comfortable lying space, allowing cows to lie in stretched positions (Krohn and Munksgaard, 1993) and may reduce incidences of lameness and mastitis compared to indoor housing (Fregonesi and Leaver, 2001; Haskell et al., 2006). However, as milk yields increase, pasture alone may be insufficient to meet nutritional requirements, which could result in cattle on pasture becoming hungry (Kolver and Muller, 1998), reducing their welfare. Indoors, feed such as a Total Mixed Ration (TMR) is often fed to dairy cattle, allowing them to more easily meet their nutritional demands and therefore maintain milk yields (Kolver and Muller, 1998). Climatic conditions (Schütz et al., 2010), managing pasture quality and availability and the use of automatic milking systems (AMS) may also influence the decision to house cows indoors. However, the welfare of cattle indoors may be reduced. Housing design (Tucker et al., 2004b) and bedding quality can influence lying times (Fregonesi et al., 2007a), reduced space allowance can lead to increased aggression (Fregonesi and Leaver, 2002), incidences of mastitis (Washburn et al., 2002) and lameness may increase (Vanegas et al., 2006), and natural behaviours may be restricted (Miller and Wood-Gush, 1991). There are clear benefits of 
pasture access and indoor housing and there are also aspects of both environments which may compromise dairy cow welfare.

The emerging field of Precision Livestock Farming (PLF) may provide solutions to the issues raised above. PLF is already having a big impact in dairy cow management (Rutter, 2012), and technology has the potential to facilitate the management of pasture access and, possibly, to help make 'smart' management systems that adapt to cow behaviour and are better able to meet the needs of cows all year around.

This article aims to review the behaviour of dairy cattle that have access to pasture; to determine how cows spend their time when they are given the choice of indoor housing and pasture, what factors influence preference, the benefits of pasture access and postulates how advances in precision livestock farming could provide dairy cattle with an environment better able to meet their needs.

\section{Preference for pasture and the effect of pasture access on time budgets}

Preference testing allows animals to choose which environment or commodity they prefer and can give us some indication of what is better or worse for animal welfare (Dawkins, 2003). Research offering cows a choice of spending their time indoors or on pasture has found that dairy cow preference for indoor housing or pasture is complex, with numerous factors influencing preference and resulting in time spent on pasture ranging from 9\% to over 70\% (Krohn et al., 1992; Charlton et al., 2011a; Motupalli et al., 2014). Pasture use can depend on the season (Charlton et al. 2011b), weather conditions (Legrand et al., 2009), the location of food (Charlton et al., 2011b), distance between indoor housing and pasture (Charlton et al., 2013) and time of day, with a stronger preference to be at pasture during the night (Charlton et al., 2011b, 2013; Legrand et al., 2009; Motupalli et al., 2014).

Cattle are grazing animals and have a distinct diurnal feeding pattern (Phillips, 2002). Intake is usually split into several meals over the day, with the largest meal in the evening (Shabi et al., 2005). 
Feeding behaviour can be influenced by milk yield, with high yielding cows consuming more food and spending longer eating than low yielding cows (Tapki and Şahin, 2006; Charlton et al., 2011b) in an attempt to meet their nutritional demands and sustain production. Cows at pasture may spend 9.5 h/d grazing (Kennedy et al., 2009; O'Driscoll et al., 2010). Foraging for food and grazing is more time consuming compared to eating a TMR, and therefore cows are likely to spend longer feeding at pasture compared to indoors. Sward height and quality can influence grazing behaviour (Kirkland and Patterson, 2006; Ribeiro Filho et al., 2005). Grazing times may also be reduced if a supplement is provided (Hetti Arachchige et al., 2013) or if pasture access is restricted (Kennedy et al., 2009). Cows without pasture access will spend, on average 3 to $5 \mathrm{~h} / \mathrm{d}$ eating (DeVries et al., 2004; DeVries and von Keyserlingk, 2005), split into approximately 7 meals/d (DeVries et al., 2003b). However, the type of indoor housing can influence eating times $(5.6$ vs. 5.2 h/d, for cubicle housing vs. straw yard, respectively). Indoors, competition at the feed fence (DeVries et al., 2004) and delivery of fresh food (DeVries and von Keyserlingk, 2005) can also influence intake.

Charlton et al. (2011a, 2011b) found that when dairy cattle were given a choice between indoor housing and pasture, the cows generally chose to be indoors immediately following morning and afternoon milking, probably to eat TMR. Other studies have also observed a peak in feed intake following milking (DeVries et al., 2003a; Legrand et al., 2009). Delivery of fresh feed is also likely to have influenced this decision (Charlton et al. 2011a). When cows had a choice between eating TMR indoors or grazing at pasture they spent between $23.4 \%$ and $35.1 \%$ of their time eating in both locations (Charlton et al., 2011a, 2011b, 2013), and in agreement with Krohn et al. (1992), the cows chose to eat a mixture of the TMR and grass, but in different proportions. Krohn et al. (1992) reported that the cows spent $76 \%$ of their total eating time eating the TMR and $24 \%$ grazing. Charlton et al. (2011a, 2011b, 2013) found the cows spent between $18 \%$ and $44 \%$ of their total eating time, grazing. The amount of time spent eating depends on the type of food eaten, for example, TMR can be consumed more quickly than grazed herbage. It can also depend on quality of the food and its availability (Ginane and Petit, 2005), bite and intake rate (Gibb et al., 1998), body condition score (BCS) (Tucker et al., 2007), and nutritional requirements of the animal. 
112 Lying down and resting are both high-priority activities for dairy cows (Krohn and Munksgaard, 113 1993; Munksgaard et al., 2005) and are essential to maintain good health and welfare and high 114 productivity levels (Tucker et al., 2004a). When dairy cows are provided with a suitable lying area 115 they will choose to rest for 8-14 hours per day, over 8-25 lying periods (Krohn and Munksgaard, 116 1993; Tucker et al., 2004a), with preference for lying during the evening and night time (Broom and Fraser, 2007; Wierenga and Hopster, 1990).

Lying times of 10.9 to $12.6 \mathrm{~h} / \mathrm{d}$ were reported for pregnant cows and heifers on pasture (Chen et al., 2017; Hernandez-Mendo et al., 2007). Indoors, lying times can vary greatly and the type of housing can affect the time budget of dairy cows (Munksgaard et al., 2005). Charlton et al. (2014) reported lying times of 8.7 to $13.2 \mathrm{~h} / \mathrm{d}$ for dairy cows in cubicle housing. Lactating cows in a compost bedded pack spent 8.6 to $11.4 \mathrm{~h} / \mathrm{d}$ lying (Endres and Barberg, 2007) and lying times in a straw yard varied between 12.3 to $14.1 \mathrm{~h} / \mathrm{d}$ (Fregonesi and Leaver, 2001; Fregonesi and Leaver, 2002).

Pasture can provide dairy cattle with ample, comfortable lying space, which allows them to easily transition between lying and standing and to lie in more stretched positions and even on their sides (Krohn and Munksgaard, 1993), which is not always possible indoors, especially in cubicles. Lying behaviour in cubicle housing can be affected by design and management practices, such as lying surface (Tucker et al., 2003), bedding type (Haley et al., 2001), bedding quality and quantity (Tucker and Weary, 2004; Drissler et al., 2005; Fregonesi et al., 2007a), cubicle size and design (Tucker et al., 2004b), cubicle availability (Fregonesi et al. 2007b) and management procedures such as feeding and milking (Overton et al., 2002; DeVries and von Keyserlingk, 2005). When lying areas are unsatisfactory cows indoors may choose to lie in alleyways (Manninen et al., 2002) or reduce lying times and the number of lying bouts (Wechsler et al., 2000) which can negatively affect their welfare. Unsatisfactory lying conditions are not limited to indoor housing. At pasture, Chen et al. (2017) reported lying times of $12.6 \mathrm{~h} / \mathrm{d}$, however lying time reduced to as low as $3.2 \mathrm{~h} / \mathrm{d}$ when the soil was very muddy, and the cows even chose to lie on concrete rather than pasture when it became very wet. 
140 Studies comparing lying times of cows at pasture to those housed indoors with cubicles have shown

141 inconsistent findings. Olmos et al. (2009) found that cows on pasture had longer lying times (10.3 vs.

$1429.1 \mathrm{~h} / \mathrm{d}$ ) and showed fewer interruptions to their lying behaviour (8.2 vs. 11.4 lying bouts (LB)/d) than 143 cows housed indoors on cubicles bedded with a rubber mat. Hernandez-Mendo et al. (2007) however, 144 found that cows at pasture had shorter lying times (10.9 vs. $12.3 \mathrm{~h} / \mathrm{d})$ and lay down more often $(15.3$ vs. 12.2 LB/d) than cows housed indoors with sand bedded cubicles. Differences in lying behaviour may be a result of feed quantity and quality provided both indoors and at pasture. Lying comfort may also vary between the cubicles with mats and sand bedded cubicles, influencing lying times (Tucker et al., 2003). Alternatively, the cubicles indoors may restrict the cows from standing and the pasture may provide a more comfortable standing surface compared to the concrete flooring indoors (Hernandez-Mendo et al., 2007).

When given a choice between lying indoors in cubicles or lying at pasture, the total lying time across the two areas varied between $43.8 \%$ and 58.3\% (Charlton et al., 2011a, 2011b, 2013). Legrand et al. (2009) found that during the summer cows spent approximately $30 \%$ of their total lying time indoors, but preferred lying on pasture. Krohn et al. (1992) reported that during the summer months cows spent the majority of their time on pasture (over $70 \%$ of their time), and preferred lying outdoors. However, during the winter months the cows reduced pasture use to approximately $20 \%$ per day, and preferred lying indoors, on straw bedding. Charlton et al. (2013) found that although the absolute time spent lying indoors was higher than that recorded at pasture, the relative proportion of time spent lying on pasture was higher than indoors $(44.9 \%$ vs. $54.0 \%$; for lying indoors vs. lying on pasture, respectively). However, the recording of behavioural activities in this study was limited to daylight hours, so lying times on pasture may have been higher, especially as the cows spent most of their time on pasture during the night, and cattle have been found to spend the majority of the night time lying (Tolkamp et al., 2010). 
As well as feeding and lying time, time spent walking may also be influenced when cows have access to pasture. Research by Charlton et al. (2011a, 2011b, 2013) found walking time was higher on pasture compared to indoors. Natural grazing behaviour involves slowly walking forward (Broom and Fraser, 2007) which may explain the increased walking times on pasture. Indoors, movement may have been restricted by the design of the housing (Boyle et al., 2008) as forward movement whilst eating is not necessary when food is provided at a feed fence.

\section{Positives and negatives of pasture and indoor housing}

Pasture is a natural environment for dairy cattle, and despite concerns about climatic conditions there are numerous health and welfare benefits of providing dairy cattle with access to pasture compared to being continuously housed (see Arnott et al., 2016 for a health-focussed review). Studies have shown that even partial pasture access can have beneficial effects compared to total confinement (Chapinal et al., 2010; Washburn et al., 2002).

\subsection{Weather conditions}

At pasture, cattle can be exposed to a range of weather conditions including rain, wind and solar radiation, which may affect behaviour and physiology (Schütz et al., 2010), and reduce welfare. Indoors, concerns about environmental conditions affecting welfare are much lower, as cattle are often protected from the extremes in environmental conditions, and although climatic control of dairy barns is not common in maritime climates such as the United Kingdom, in hot climates it is possible to control ambient temperature with ventilation systems and air conditioning.

Cattle have a thermoneutral zone (Laloni et al., 2003), which ranges between $2-25^{\circ} \mathrm{C}$ for lactating dairy cows (Berman et al., 1985; Albright and Arave, 1997). Thermal comfort can also be measured using a temperature-humidity index (THI), with a THI $>72$ (equal to $25^{\circ} \mathrm{C}$ and $50 \%$ humidity) usually accepted as the upper critical climate (Igono et al., 1992; Kendall et al., 2006). When given a choice, preference to be indoors or at pasture was not affected when the average THI remained within the thermal comfort zone for dairy cows (Charlton et al., 2011a, 2013). However, Legrand et al. (2009) 
found that during the daytime when the THI was high, the cows spent more time indoors, which they were likely using for shade. Langbein and Nichelmann (1993) reported that cattle on pasture exposed to temperatures up to $28^{\circ} \mathrm{C}$ spent $85 \%$ of each hour in shade.

When temperatures are high, behavioural and physiological changes occur in an attempt to reduce heat load and cattle are extremely motivated to access shade to reduce respiration rate and body temperature (Schütz et al., 2008; Schütz et al., 2010). Increased head load can cause numerous negative effects. For example, nutritional needs may change (West, 2003), feeding activities decrease, diurnal patterns of activity may alter (Langbein and Nichelmann, 1993; Tapki and Şahin, 2006), production levels are reduced (West, 2003) and lying times decrease (Schütz et al., 2010). With excessive heat load the quality of colostrum composition is lowered (Nardone et al., 1997), reproductive efficiency declines (García-Ispierto et al., 2007), the animals immune system function is reduced, resulting in increased susceptibility to disease (Webster, 2005) and in some cases it may even lead to death (St-Pierre et al., 2003).

The behaviour and welfare of cows on pasture may also be affected when exposed to inclement weather conditions (Phillips, 1993; Tucker et al., 2007). Studies which have allowed cows a choice between indoor housing and pasture have found that rainfall influenced time spent on pasture, with the cows spending more time indoors on rainy days (Charlton et al., 2011a; 2013; Legrand et al., 2009) and on frosty, winter days (Krohn et al., 1992). Ketalaar-de Lauwere et al. (2000) also reported changes in cow behaviour when it rained, and on days with heavy rain, Ketelaar-de Lauwere et al. (1999) found that cows either stopped their behavioural activity or returned to the indoor housing.

Exposure to cold and wet winter weather can cause a reduction in lying times, an increase in time standing in postures which may reduce the amount of surface area exposed to the wind and rain and an increase in cortisol concentrations compared to cows housed indoors (Tucker et al., 2007). Langbein and Nichelmann (1993) reported that during the rainy season, Holstein Friesian cattle spent less time grazing and Vandenheede et al. (1995) found that cattle spent three times longer under 
shelter during hours when it rained compared to hours without rain. Charlton et al. (2011b) found that preference for pasture declined between mid-August and early November, likely due to deteriorating weather and ground conditions. Even in the absence of rain or wind, muddy ground conditions are aversive for dairy cattle and can compromise welfare (Chen et al., 2017).

These findings show how extreme weather conditions can influence the behaviour and physiological responses of cattle, and reduce welfare. Therefore, indoor housing may be more suitable for the welfare of cattle during the winter months and also in summer if the ambient temperature exceeds $25^{\circ} \mathrm{C}$, as it provides shelter from the environmental conditions and it is easier to control temperatures. Alternatively, the cows should be provided with plenty of shade and shelter from the wind and rain when outdoors, in an attempt to maintain welfare.

\subsection{Lameness}

Lameness is a source of chronic pain for dairy cows and is one of the most common welfare problems within UK dairy herds (Webster, 1994). Major housing and feeding changes, such as an increase in the use of starchy feeds and silage since the middle of the twentieth century have largely contributed to an increase in lameness in dairy cattle (Webster, 1994). Pain from foot and leg problems can impair behaviour (Broom and Fraser, 2007). Lame cows may have restricted locomotion and movement (Telezhenko and Bergsten, 2005), a reduction in the expression of oestrus (Walker et al., 2008), a change in body posture indicative of pain and discomfort (Sprecher et al., 1997), a reduction in feeding time, and a change in standing and lying behaviour (Gomez and Cook, 2010; Blackie et al., 2011). Lameness also causes financial losses as a result of a reduction in milk yield, a decline in reproductive success, and an increase in treatment costs and culling rates (Green et al., 2002; Juarez et al., 2003; Booth et al., 2004).

Research has shown that the prevalence of lameness is significantly greater when cows are housed indoors compared to pasture (Somers et al., 2005b; Olmos et al., 2009). A study by Haskell et al. (2006) found that there was double the number of lame cows on zero grazed farms, compared to 
farms which allowed cows access to pasture to graze. Furthermore, the study revealed that of the

251

252

253

254

255

256

257

258

259

260

261

262

263

264

265

266

267

268

269

270

271 indoor housing systems, lameness was higher on farms with cubicle housing compared to those with straw yards.

Higher incidences of lameness in indoor cubicle systems may be a result of the flooring. Most indoor cubicle housing systems have concrete flooring which is unnaturally hard compared to the softness of pasture, increasing the likeliness of hoof damage. The design of cubicles may also contribute to the increase in lameness (Somers et al., 2005a; Haskell et al., 2006) and the social status of animals could play a role, as low ranking animals are more likely to stand half in cubicles in an attempt to avoid dominant animals (Galindo et al., 2000). This unnatural posture may lead to a reduction in heel depth, increasing the chances of infection and resulting in clinical lameness (Galindo et al., 2000). It is also suggested that the exposure of claws to faeces is a likely cause for the increase of lameness indoors (Somers et al., 2005b). The acidity of the slurry can also soften and erode the hoof (Webster, 1987). It is likely that wetter slurry, caused by cattle eating wet silage, increases foot problems. The presence of slurry on concrete floors also reduces walking speed and alters walking patterns of cattle as they attempt to reduce the risk of slipping (Phillips and Morris, 2000).

Hoof health may be improved by a period at pasture (Hernandez-Mendo et al., 2007). Pasture provides a soft, comfortable surface which allows proportional pressure on the claw, allowing the feet to recover and reducing further hoof damage (Hernandez-Mendo et al., 2007). The friction level of the soft soil also reduces the risk of cows slipping. Olmos et al. (2009) suggests a period on pasture of at least 85 days to allow cows to recover from hoof disorders and lameness. Yet, Hernandez-Mendo et al. (2007) reported improvements in gait scores after just four weeks on pasture. However, this period on pasture resulted in reduced milk yield, and the cows lost more weight relative to cows housed indoors. In an attempt to prevent these consequences, Chapinal et al. (2010) limited pasture access to the night time and the results showed that milk production and TMR intake were not affected, but night time pasture access did not have clear beneficial effect on gait score. Somers et al. (2005b) 
found that restricting grazing time (i.e. being kept indoors at night) was highly associated with digital and interdigital dermatitis and hoof erosion, which can lead to lameness.

Waking to and from pasture can also have beneficial effects on hoof health and overall health and welfare of the animal (Bielfeldt et al., 2005; Regula et al., 2004). During exercise, blood flow to the claw is stimulated, improving the transport of nutrients and oxygen to the horn-producing area (Bielfeldt et al., 2005). However, the track should be well maintained with good drainage and small stones removed to avoid injuries to the claws of the cows (Vermunt, 2006). The cows should also be moved down the track calmly and with patience (Hulsen, 2005). Changes to management can reduce the incidence of lameness, and the same principles can be applied to indoor housing systems. It is possible, with changes to the management and design of indoor housing to provide cows with an environment which reduces the occurrence of lameness and maintains milk yield and body condition (Haskell et al., 2006). Regular foot trimming and foot bathing (Haskell et al., 2006), regular floor scraping (Somers et al., 2005a; Somers et al., 2005b) to remove slurry and reduce the time cattle spend standing in it, and softer flooring, such as rubber mats (Telezhenko and Bergsten, 2005; Vanegas et al., 2006) can increase locomotion and are beneficial for hoof health, reducing lameness. Changes to the cubicle design can also improve hoof health. Longer cubicles increase the lunging space and reduce lameness (Somers et al., 2005b; Haskell et al., 2006), and cubicles with unrestricted neck rails can reduce the risk of lameness and increase cow comfort, but this may be at the expense of udder and cubicle cleanliness (Bernardi et al., 2009; Fregonesi et al., 2009).

\subsection{Udder health}

Poor udder health is a major animal welfare concern which can cause considerable pain and distress (Fall et al., 2008). In general, cattle housed indoors are at greater risk of environmental mastitis than cows on pasture. Goldberg et al. (1992) showed that fewer udder health problems occurred per month in cows that had been kept on pasture than those kept indoors. Similarly, Washburn et al. (2002) reported fewer cases of clinical mastitis for cows on pasture than those housed indoors with cubicles. With more lying space outdoors, cattle have a greater opportunity to avoid each other's personal space 
and dirty lying areas. Indoors, several studies have reported a greater incidence of mastitis in straw yards compared to cubicle housing (Peeler et al., 2000; Fregonesi and Leaver, 2001). Limited space in a straw yard can result in teats being trodden on, and the cleanliness of the straw is likely to increase the risk of infection (Schreiner and Ruegg, 2003).

\subsection{Productivity}

One of the main concerns of incorporating pasture into the management of high-yielding dairy cattle is that they may not be able to meet their nutritional demands (Fike et al., 2003), and grazing alone could compromise their freedom from hunger, and limit productivity. Fontaneli et al. (2005) reported that cows on pasture produced $19 \%$ less milk than those in confined housing, and similarly Hernandez-Mendo et al. (2007) found that compared to cows housed indoors, cows continuously housed on pasture produced less milk and lost more weight, and this is often the reason dairy cows are kept indoors. However, if cows have access to TMR indoors then it may be possible to allow them access to pasture and to maintain intake and production levels (Chapinal et al., 2010). Furthermore, Motupalli et al. (2014) found that cows given a choice of spending their time indoors with access to a TMR or to pasture produced, on average, $6.7 \mathrm{~kg} / \mathrm{d}$ more milk than cows continuously housed. This substantial increase in milk yield may be a result of higher lying times and the addition of grass intake. Allowing cows control over their environment may also have contributed to these finding, resulting in welfare and production benefits for dairy cattle.

\section{Factors affecting preference}

The preference of dairy cows to be indoors or on pasture is complex, with numerous factors influencing where cows choose to spend their time. Milk yield appears to affect preference, with high yielding cows spending more time indoors than lower yielding cows (Charlton et al., 2011a). The intake rate of TMR is higher than that of grazed herbage (Bargo et al., 2002; Holden et al., 1994), so cows with a higher nutritional requirement may choose to be indoors, closer to the TMR, so they can meet their nutritional demands and still have time for other high priority activities such as lying and ruminating. Lameness may also influence preference, with cows with a greater degree of lameness 
(i.e. a higher lameness score) spending more time indoors (Charlton et al., 2011b). Pasture is a soft, comfortable surface which can provide a period of recovery for lame cows (Hernandez-Mendo et al., 2007), whereas indoors, concrete flooring is not an ideal surface, especially when covered in slurry as it can cause damage to the hoof (Phillips and Morris, 2000), and natural locomotion behaviour may be impaired (Cook and Nordlund, 2009).

\subsection{Previous experience}

Charlton et al. (2011a; 2011b) found conflicting results on time spent at pasture when cows were given a choice between indoor housing and pasture. One of the main differences between the two studies was the rearing of the cows and their previous experience. The cows in Charlton et al. (2011a) had been reared indoors, and although they had access to pasture prior to the study they had little experience of pasture or grazing. In the study of Charlton et al. (2011b) the cows had greater experience of pasture and grazing, and from a young age were given access to pasture during the summer months. Previous experience can influence preference (Kirkden and Pajor, 2006), so it is possible that the cows without pasture experience expressed a partial preference to be indoors as this was the environment they were more familiar with.

A follow up study by Motupalli et al. (2013) to determine if previous experience influenced preference for pasture vs. housing found that cows without prior experience of pasture spent $79.0 \%$ of their time indoors and $13.6 \%$ of their time at pasture compared to $54.9 \%$ of time spent indoors and $37.0 \%$ at pasture, for animals reared with experience of pasture. Also, the cows without pasture experience spent more time investigating grass and less time grazing than those with pasture experience. These results suggest that preference for pasture and grazing behaviour are learned, which then raises two questions: do cattle miss pasture access (and grazing) if they have never experienced it? If so, then if cattle are to be housed for part of the year, would it be better for them to never experience pasture and to house them continuously? If grazing is not instinctive then it is possible that cows without experience of grazing do not have the motivation to graze, and therefore will not experience frustration when prevented from performing such behaviour. Indeed, cows allowed pasture 
access for part of the year may experience more frustration than zero grazed cattle, as they have developed the motivation to graze, and the desire access to more space and a comfortable lying area, yet are denied this for several months of the year. Philosophical arguments about whether animals can 'miss' something they have never experienced are beyond the scope of this review. Also, at a practical level, such arguments are countered by the clear production, health and welfare benefits of pasture for dairy cattle, as discussed earlier. On the balance of current evidence, the wide-ranging benefits of pasture access appear to outweigh possible negative consequences of frustration associated with lack of access to pasture in the winter, although further research in this area is needed.

\subsection{Distance between indoor housing and pasture}

When dairy cows have access to indoor housing and pasture, the distance between the two locations may influence where the cows choose to spend their time (Charlton et al., 2013; Motupalli et al., 2014). A study by Ketelaar-de Lauwere et al. (2000) investigated the effect of distance between indoor housing and pasture and the results revealed that cows preferred lying on pasture, even when the distance between the indoor housing and pasture was $360 \mathrm{~m}$. The cows also preferred grazing, rather than eating forage indoors. However, as the sward height decreased, use of the indoor area increased. Spörndly and Wredle (2004) also investigated the effect of distance between indoor housing and pasture on cow behaviour and the use of an automatic milking system (AMS). In contrast to the finding of Ketelaar-de Lauwere et al. (2000) the results revealed that distance did influence pasture use. Cows allowed access to near pasture (50 $\mathrm{m}$ from the indoor housing) spent $68 \%$ of their time outdoors and spent $20 \%$ of their time grazing and preferred lying on pasture, whereas those on distant pasture (260 $\mathrm{m}$ from the indoor housing) spent significantly less time on pasture ( $44 \%$ of their time) and preferred lying indoors. Similar results for daytime pasture access were reported by Charlton et al. (2013).

\section{Motivation for pasture}

A limitation of preference testing is that it fails to provide information on the strength of preference and whether the animal prefers one option or is simply avoiding the alternative (Fraser and Matthews, 
1997). Motivational tests can be useful to determine the behavioural needs of an animal (Edwards, 2010). One approach is to use operant conditioning techniques, where motivational strengths are measured by imposing an increasing cost of access to perform particular behaviours (Jensen and Pedersen, 2008).

Research using motivational tests suggest that pasture access is important for dairy cattle. To test the motivation of cows to access pasture, Charlton et al. (2013) conducted a study to determine whether providing pasture access 60,140 or $260 \mathrm{~m}$ from the indoor housing would influence pasture use. The study revealed that at night time the cows spent an average of $79.6 \%$ of their time on pasture, which was not influenced by the distance, whereas during the day pasture use declined with increasing distance. These findings suggest that night time pasture access is important for dairy cattle, and they are motivated to walk $260 \mathrm{~m}$ to access the pasture. This is possibly because they do not generally eat at night (Rutter, 2006) so they may have had a lower requirement to be close to the TMR at night compared to the day. Air temperature is usually lower at night, reducing the need of shelter from the sun and, as cows spent a large proportion of their time lying at night time, the pasture may have been more comfortable than the cubicles indoors. Similar results were also reported by Motupalli et al. (2014). In addition, Cestari et al. (2013) found that when dairy cattle were required to push through a weighted gate to gain access to pasture, cows that were normally housed indoors were just as motivated to access pasture as they were to access fresh TMR following milking.

\section{Areas for future research}

Compared with cubicle housing, pasture provides cows with different resources that serve a variety of functions: ground which is usually less slippery and softer than concrete; open space in which to move and also interact with or avoid other cows; open areas and a different substrate on which to lie down, and the ability to graze herbage and possibly browse from hedges or trees. To date, studies on pasture access have not attempted to explore the relative importance of these different functions, and research into the comparative motivation of cows for these different aspects of pasture is needed. 
417 Although Motupalli et al. (2014) showed that offering cattle a choice between pasture and cubicle

418 housing improved both animal welfare and production, it is possible that some (or even all) of these

419 benefits derived from simply offering the animals a choice (rather than deriving from pasture access

420 per se). There is increasing recognition of the importance of choice for animal welfare, with Webster

421 (2016) recently arguing that one of the FAWC (1993) Five Freedoms i.e. 'freedom to express normal

422 behaviour' would be better expressed as 'freedom of choice'. He believes this would address his greatest criticism of 'factory farming' i.e. "by assuming more or less total control of the physical and social environment, we deny the animals the opportunity to make choices designed to promote their own quality of life". Although a variety of studies have demonstrated the animal welfare benefits of offering captive animals a choice and a degree of control over their environment, the majority of research to date has focussed on providing choice and control to zoo animals (Kurtycz, 2015). Further research is needed to explore the benefits (for animal welfare and production) of giving a greater element of choice to farm animals, especially those kept under intensive management and continuously housed.

Offering high-yielding dairy cows continuous free choice between cubicle housing and pasture becomes increasingly difficult as herd size increases as it requires long tracks to access the large areas of pasture required. As demonstrated by Ketelaar-de Lauwere et al. (2000) and Charlton et al. (2013), cows will reduce their use of pasture if they have to walk a long way to access it. This is where the emerging field of Precision Livestock Farming (PLF) could play a key role in facilitating cow choice on dairy farms in the future. Automatic milking systems (AMSs) are already being used on an increasing number of commercial dairy farms (Jacobs and Siegford, 2012), and such systems demonstrate how technology can facilitate farm animal choice i.e. enabling the cow to choose when and how often she is milked. Automatic milking systems also reduce cow stress as they dramatically reduce aversive contact with humans and close contact with conspecifics at milking time compared with traditional parlours (Bruckmeier, 2010). Each AMS typically milks approximately 60 cows

443 (Jacobs and Siegford, 2012) and so large herds could be split into a number of smaller units, each with 444 a separate building with one (or at the most two) milking robots and surrounded with sufficient 
pasture within easy walking distance for the small group. This would have the added benefit of

446 keeping the cows in smaller, more socially appropriate group sizes.

448 One likely factor that contributes to the production benefit of pasture access is that it offers animals an alternative source of feed to the single TMR offered indoors. There is evidence that grazing cattle can and, when given the opportunity, do select diets that optimise their own efficiency of nutrient capture (Rutter, 2006). Although TMRs are formulated to meet the nutritional needs of the 'average' cow in the herd (or feeding group), they are likely to be sub-optimal for a significant proportion of the animals in the group (Atwood et al., 2006). Manteca et al. (2008) and Rutter (2010) have argued that TMRs could compromise animal welfare as they remove (or at least severely restrict) the cow's ability to select their own diet, leading to frustration and stress. Fully automated feeding systems are now being used on commercial dairy farms. These replace manually driven mixer wagons and so reduce labour costs and enable more regular feed delivery. These automated feeding systems could also facilitate diet choice as they could be used to deliver e.g. two different partial mixed rations (PMRs). These could be formulated so that cows can select a combination of the two PMRs that meets their own nutritional requirements. As well as potentially improving welfare by enabling diet choice, production efficiency could be significantly increased (Atwood et al., 2006).

Another likely benefit of pasture is that, compared with cubicles, it provides a more comfortable place for animals to lie down. The design of cubicles i.e. rectangular shapes in straight rows is, in part, to facilitate manure removal by scrapers pulled through straight, fixed-width passages. The development of autonomous robotic scrapers that can turn, scrape around curves and clean large, open areas means that the need for straight rows of rectangular cubicles is removed and radical new designs of cow lying spaces can be now be considered.

Finally, commercial systems that allow the locations of all the animals in the herd to be determined

471 and tracked over time have the potential to help make housing more 'adaptive'. For example, it should 472 be possible to increase the ventilation in one part of the building by automatically opening side 
473 curtains or adjusting fan speeds and then see how the cows respond. If more cows move into the area

474 with increased ventilation, more side curtains could be opened or others fans adjusted to meet the

475 'demand'. Later, cows may start to move to the more sheltered part of the building, and consequently

476 the side curtains could start to be closed. In this way the building could adapt to the behaviour of the

477 cows and help facilitate their choice of environment.

478

479 These potential technological solutions to achieving the welfare and production benefits of pasture

480 access require further research, not least an economic cost-benefit analysis. However, it is possible

481 that they could contribute to the design of novel dairy cow housing that, by facilitating cow choice,

482 improve production efficiency and animal welfare by meeting the needs of the cows all year around.

483

484 7. Conclusion

485 Research has shown that preference of dairy cows for indoor housing or pasture is complex; there are

486 benefits to both locations and preference is influenced by several environmental and animal factors,

487 including climatic conditions, walking distance, lameness, milk yield and previous experience.

488 Although there are clear benefits to allowing cows a choice of where to spend their time this is not

489 always a practical solution for dairy farmers, and therefore ongoing developments in Precision

490 Livestock Farming may offer the potential to provide a technological solution to this problem. These

491 advances may allow farmers to incorporate the best aspects of pasture with the best aspects of housing to provide an environment that meets the needs of cows all year around. 


\section{References}

Albright, J.L and Arave, C.W., 1997. The Behaviour of Cattle. Wallingford: CAB International.

Arnott, G., Ferris, C.P. and O'Connell, N.E. 2016. Review: welfare of dairy cows in continuously housed and pasture-based production systems. Animal. doi: 10.1017/S1751731116001336

Atwood, S. B., Provenza, F. D., Villalba, J. J. and Wiedmeier, R. D. 2006. Intake of lambs offered ad libitum access to one of three iso-caloric and iso-nitrogenous mixed rations or a choice of all three foods. Livest. Sci. 101, 142-149.

Bargo, F., Muller, L.D., Delahoy, J.E. and Cassidy, T.W., 2002. Performance of high producing dairy cows with three different feeding systems combining pasture and total mixed rations. J. Dairy Sci. 85, 2948-2963.

Barkema, H.W., von Keyserlingk, M.A.G., Kastelic, J.P., Lam, T.J.G.M., Luby, C., Roy, J.-P., LeBlanc, S.J., Keefe, G.P., and Kelton, D.F. 2015. Invited review: Changes in the dairy industry affecting dairy cattle health and welfare. J. Dairy Sci. 98, 7426-7445.

Berman, A., Folman, Y., Kaim, M., Mamen, M., Herz, Z., Wolfenson, D., Arieli, A. and Graberi, Y., 1985. Upper critical temperatures and forced ventilation effects for high-yielding dairy cows in a subtropical climate. J. Dairy Sci. 68, 1488-1495.

Bernardi, F., Fregonesi, J., Winckler, C., Veira, D.M., von Keyserlingk, M.A.G. and Weary, D.M., 2009. The stall-design paradox: Neck rails increase lameness but improve udder and stall hygiene. J. Dairy Sci. 92, 3074-3080.

Bielfeldt, J.C., Badertscher, R., Tölle, K.-H. and Krieter, J. 2005. Risk factors influencing lameness and claw disorders in dairy cows. Livest. Prod. Sci. 95, 265-271.

Blackie, N., Bleach, E., Amory, J. and Scaife, J., 2011. Impact of lameness on gait characteristics and lying behaviour of zero grazed dairy cattle in early lactation. Appl. Anim. Behav. Sci. 129, $67-73$.

Booth, C.J., Warnick, L.D., Gröhn, Y.T., Maizon, D.O., Guard, C.L. and Janssen, D., 2004. Effects of lameness on culling in dairy cows. J. Dairy Sci. 87, 4115-4122. 
Boyle, L.A., Boyle, R.M. and French, P. 2008. Welfare and performance of yearling dairy heifers out-wintered on a wood-chip pad or housed indoors on two levels of nutrition. Animal. 2, 769778.

Broom, D.M. and Fraser, A.F. 2007. Domestic Animal Behaviour and Welfare. 4th edition. Wallingford: CABI Publishing.

Bruckmaier, R.M., 2010. The impact of robotic milkers on cow welfare. WCDS Advances in Dairy Tech. 22, 267-273.

Cardoso, C.C., Hötzel, M.J, Weary, D.M., Robbins, J.A., and von Keyserlingk, M.A.G., 2016. Imagining the ideal dairy farm. J. Dairy Sci. 99. 1663-1671.

Cestari, A.A., Fregonesi, J.A., Weary, D.M. and von Keyserlingk, M.A.G., 2013. Motivation for access to pasture in dairy cows. In: Proceedings of the $47^{\text {th }}$ Congress of the International Society for Applied Ethology, Florianopolis, Brazil, 2-6 June 2013. Pp 115.

Chapinal, N., Goldhawk, C., de Passillé, A.M., von Keyserlingk, M.A.G. Weary, D.M. and Rushen, J., 2010. Overnight access to pasture does not reduce milk production or feed intake in dairy cattle. Livest. Sci. 129, 104-110.

Charlton, G.L., Haley, D.B., Rushen, J. and de Passillé, A.M. 2014. Stocking density, milking duration, and lying times of lactating cows on Canadian freestall dairy farms. J. Dairy Sci. 97, 2694-2700.

Charlton, G.L, Rutter, S.M., East, M., and Sinclair, L.A., 2011a. Preference of dairy cows: indoor cubicle housing with access to a total mixed ration vs. access to pasture. Appl. Anim. Behav. Sci. $130,1-9$.

Charlton, G.L, Rutter, S.M., East, M., and Sinclair, L.A., 2011b. Effects of providing total mixed rations indoors and on pasture on the behavior of lactating dairy cattle and their preference to be indoors or on pasture. J. Dairy Sci. 94, 3875-3884.

Charlton, G.L., Rutter, S.M., East, M., and Sinclair, L.A., 2013. The motivation of dairy cows for access to pasture. J. Dairy Sci. 96, 4387-4396. 
Chen, J.M., Stull, C.L., Ledgerwood, D.N. and Tucker, C.B. 2017. Muddy conditions reduce hygiene and lying time in dairy cattle and increase time spent on concrete. J. Dairy Sci. 100, 2090-2103.

Cook, N.B. and Nordlund, K.V., 2009. The influence of the environment on dairy cow behavior, claw health and herd lameness dynamics. The Vet. J. 179, 360-369.

DairyCo. 2016. Available at: http://dairy.ahdb.org.uk/market-information/farming-data/milkyield/average-milk-yield/\#.WCSH5YbfWEc (last accessed 21.10.2016).

Dawkins, M.S. 2003. Behaviour as a tool in the assessment of animal welfare. Zoology, 106, 383387.

DeVries, T.J. and von Keyserlingk, M.A.G., 2005. Time of feed delivery affects the feeding and lying patterns of dairy cows. J. Dairy Sci. 88, 625-631.

DeVries, T.J., von Keyserlingk, M.A.G. and. Beauchemin, K. A., 2003a. Short Communication: Diurnal feeding pattern of lactating dairy cows. J. Dairy Sci. 86, 4079-4082.

DeVries, T.J., von Keyserlingk, M.A.G. and Weary, D.M., 2004. Effect of feeding space on the inter-cow distance, aggression, and feeding behavior of free-stall housed lactating dairy cows. J. Dairy Sci. 87, 1432-1438.

DeVries, T.J., von Keyserlingk, M.A.G., Weary, D.M. and Beauchemin, K.A. 2003b. Measuring the feeding behavior of lactating dairy cows in early to peak lactation. J. Dairy Sci. 86, 3354-3361.

Drissler, M., Gaworski, M., Tucker, C.B. and Weary, D.M., 2005. Freestall maintenance: effects on lying behavior of dairy cattle. J. Dairy Sci. 88, 2381-2387.

EC (European Commission). 2015. Available at: http://europa.eu/rapid/press-release_MEMO-154697_en.htm (last accessed 21.10.2016.

Edwards, L.N. 2010. Animal well-being and behavioural needs on the farm. In: T. Grandin. ed. Improving Animal Welfare: A Practical Approach. Wallingford: CABI Publishing. pp. 139-159. Endres, M.I. and Barberg, A.E. 2007. Behavior of dairy cows in an alternative bedded-pack housing system. J. Dairy Sci. 90, 4192-4200.

Fall, N., Emanuelson, U., Martinsson, K. and Jonsson, S., 2008. Udder health at a Swedish research farm with both organic and conventional dairy cow management. Prev. Vet. Med. 83, 186-195. 
Farm Animal Welfare Council (FAWC), 1993. Second Report on Priorities for Research and Development in Farm Animal Welfare; DEFRA, London, UK.

Fike, J.H., Staples, C.R., Stollenberger, L.E., Macoon, B. and Moore, J.E., 2003. Pasture forages, supplementation rate, and stocking rate effects on dairy cow performance. J. Dairy Sci. 86, 12681281.

Fontaneli, R.S., Sollenberger, L.E., Littell, R.C. and Staples, C.R., 2005. Performance of lactating dairy cows managed on pasture-based or in free stall barn-feeding systems. J. Dairy Sci. 88, 1264-1276.

Fraser, D. and Matthews, L.R. 1997. Preference and motivation testing. In: M.C. Appleby and O.B. Hughes. eds. Animal Welfare. Wallingford: CABI Publishing. pp. 159-173.

Fregonesi, J.A. and Leaver, J.D., 2001. Behaviour, performance and health indicators of welfare for dairy cows housed in strawyard or cubicle systems. Appl. Anim. Behav. Sci. 68, 205-216.

Fregonesi, J.A. and Leaver, J.D. 2002. Influence of space allowance and milk yield level on behaviour, performance and health of dairy cows housed in strawyard and cubicle systems. Livest. Prod. Sci. 78, 245-257.

Fregonesi, J.A., Tucker, C.B. and Weary, D.M., 2007b. Overstocking reduces lying time in dairy cows. J. Dairy Sci. 90, 3349-3354.

Fregonesi, J.A., Veira, D.M., von Keyserlingk, M.A.G. and Weary, D.M., 2007a. Effects of bedding quality on lying behavior of dairy cows. J. Dairy Sci. 90, 5468-5472.

Fregonesi, J.A., von Keyserlingk, M.A.G., Tucker, C.B., Veira, D.M. and Weary D.M., 2009. Neckrail position in the free stall affects standing behavior and udder and stall cleanliness. J. Dairy Sci. 92, 1979-1985.

Galindo, F., Broom, D.M. and Jackson, P.G.G., 2000. A note on possible link between behaviour and the occurrence of lameness in dairy cows. Appl. Anim. Behav. Sci. 67, 335-341.

García-Ispierto, I., López-Gatius, F., Bech-Sabat, G., Santolaria, P., Yániz, J.L., Nogareda, C., De Rensis, F. and López-Béjar, M., 2007. Climate factors affecting conception rate of high producing dairy cows in northeastern Spain. Theriogenology. 67, 1379-1385. 
Gibb, M.J., Huckle, C.A. and Nuthall, R., 1998. Effect of time of day on grazing behaviour by lactating dairy cows. Grass and Forage Sci. 53, 41-46.

Ginane, C. and Petit, M., 2005. Constraining the time available to graze reinforces heifers' preference for sward of high quality despite low availability. Appl. Anim. Behav. Sci. 94, 1-14.

Goldberg, J.J., Wildman, E.E., Pankey, J.W., Kunkel, J.R., Howard, D.E. and Murphy, B.M., 1992. The influence of intensively managed rotational grazing, traditional continuous grazing, and confinement housing on bulk tank milk quality and udder health. J. Dairy Sci. 75, 96-104.

Gomez, A. and Cook, N.B., 2010. Time budgets of lactating dairy cattle in commercial freestall herds. J. Dairy Sci. 93, 5772-5781.

Green, L.E., Hedges, V.J., Schukken, Y.H., Blowey, R.W. and Packington, A.J., 2002. The impact of clinical lameness on the milk yield of dairy cows. J. Dairy Sci. 85, 2250-2256.

Haley, D.B., de Passillé, A.M.B. and Rushen, J., 2001. Assessing cow comfort: effects of two floor types and two tie stall designs on the behaviour of lactating dairy cows. Appl. Anim. Behav. Sci. $71,105-117$.

Haskell, M.J., Brotherstone, S., Lawrence, A.B. and White, I.M.S., 2007. Characterization of the dairy farm environment in Great Britain and the effect of the farm environment on cow life span. J. Dairy Sci. 90, 5316-5323.

Haskell, M.J., Rennie, L.J., Bowell, V.A., Bell, M.J. and Lawrence, A.B., 2006. Housing system, milk production and zero-grazing effects on lameness and leg injury in dairy cows. J. Dairy Sci. $89,4259-4266$.

Hernandez-Mendo, O., von Keyserlingk, M.A.G., Veira, D.M. and Weary, D.M., 2007. Effects of pasture on lameness of dairy cows. J. Dairy Sci. 90, 1209-1214.

Hetti Arachchige, A. D., Fisher, A. D., Auldist, M. J., Wales, W. J. \& Jongman, E. C. (2013). Effects of different systems of feeding supplements on time budgets of cows grazing restricted pasture allowances. Applied Animal Behaviour Science, 148(1-2), 13-20.

Holden, L.A., Muller, L. D. and Fales, S.L., 1994. Estimation of intake in high producing Holstein cows grazing grass pasture. J. Dairy Sci. 77, 2332-2340. 
Hulsen, J. 2005. Cow Signals: A Practical Guide for Dairy Farm Management. Zutphen: Roodbont Publishers.

Igono, M.O., Bjotvedt, G. and Sanford-Crane, H.T., 1992. Environmental profile and critical temperature effects on milk production of Holstein cows in desert climate. International J. Biometeorology, 36, 77-87.

Jacobs and Siegford, J.M. 2012. Invited review: The impact of automatic milking systems on dairy cow management, behavior, health, and welfare. J. Dairy Sci. 95, 2227-2247.

Jensen, M.B. and Pedersen, L.J., 2008. Using motivation tests to assess ethological needs and preferences. Appl. Anim. Behav. Sci. 113, 340-356.

Juarez, S.T., Robinson, P.H., DePeters, R.J. and Price, E.O., 2003. Impact of lameness on behavior and productivity of lactating Holstein cows. Appl. Anim. Behav. Sci. 83, 1-14.

Kendall, P.E., Nielsen, P.P, Webster, J.R., Verkerk, G.A., Littlejohn, R.P. and Matthews, L.R., 2006. The effects of providing shade to lactating dairy cows in a temperate climate. Livest. Sci. $103,148-157$.

Kennedy, E., McEvoy, M., Murphy, J.P., and O’Donovan, M. 2009. Effect of restricted access time to pasture on dairy cow milk production, grazing behavior, and dry matter intake. J. Dairy Sci. $92,168-176$.

Ketelaar-de Lauwere, C.C., Ipema, A.H., Lokhorst, C., Metz, J.H.M., Noordhuizen, J.P.T.M., Schouten, W.G.P. and Smits, A.C., 2000. Effects of sward height and distance between pasture and barn on cows' visits to an automatic milking system and other behaviour. Livest. Prod. Sci. $65,131-142$

Ketelaar-de Lauwere, C.C., Ipema, A.H., van Ouwerkerk, E.N.J., Hendriks, M.M.W.B., Metz, J.H.M., Noordhuizen, J.P.T.M. and Schouten, W.G.P., 1999. Voluntary automatic milking in combination with grazing of dairy cows milking frequency and effects on behaviour. Appl. Anim. Behav. Sci. 64, 91-109.

Kirkden, R.D. and Pajor, E.A., 2006. Using preference, motivation and aversion tests to ask scientific questions about animals' feelings. Appl. Anim. Behav. Sci. 100, 29-47. 
Kirkland, R.M. and Patterson, D.C., 2006. The effect of quality of grass and maize silage on the intake and performance of beef cattle. Livest. Sci. 100, 179-188.

Kolver, E.S and Muller, L.D., 1998. Performance and nutrient intake of high producing Holstein cows consuming pasture or a total mixed ration. J. Dairy Sci. 81, 1403-1411.

Krohn, C.C. and Munksgaard, L., 1993. Behaviour of dairy cows kept in extensive (loose housing/pasture) or intensive (tie stall) environments II. Lying and lying-down behaviour. Appl. Anim. Behav. Sci. 37, 1-16.

Krohn, C.C., Munksgaard, L. and Jonasen, B., 1992. Behaviour of dairy cows kept in extensive (loose housing/pasture) or intensive (tie stall) environments I. Experimental procedure, facilities, time budgets - diurnal and seasonal conditions. Appl. Anim. Behav. Sci. 34, 37-47.

Kurtycz, L.M., 2015. Choice and control for animals in captivity. The Psychologist, 28, 892-895.

Laloni, L.A., Naas, I.A., Macari, M., Pereira, D.F. and Pinheiro, M.G., 2003. Model for predicting milk production in Jersey cows in hot weather. In: K. Janni. ed. Proceeding of the 5th International Dairy Housing Conference, Fort Worth, Texas, 29-31 January 2003. pp. 320-324.

Langbein, J. and Nichelmann, M., 1993. Differences in behaviour of free-ranging cattle in tropical climate. Appl. Anim. Behav. Sci. 37, 197-209.

Legrand, A.L., von Keyserlingk, M.A.G. and Weary, D.M., 2009. Preference and usage of pasture versus free-stall housing by lactating dairy cattle. J. Dairy Sci. 92, 3651-3658.

Manninen, E., de Passillé, A.M., Rushen, J., Norring, M. And Saloniemi, H., 2002. Preferences of dairy cows kept in unheated buildings for different types of cubicle flooring. Appl. Anim. Behav. Sci. $75,281-292$.

Manteca, X., Villalba, J. J., Atwood, S. B., Dziba, L. and Provenza, F. D. 2008. Is dietary choice important to animal welfare? J. Vet. Behav. 3, 229-239.

Miller, K. and Wood-Gush, D.G.M., 1991. Some effects of housing on the social behaviour of dairy cows. British Society of Anim. Prod. 53, 271-278.

Motupalli, P. R., Sinclair, L. A., Charlton, G. L., Bleach, E. C. and Rutter, S. M., 2014. Pasture access increases dairy cow milk yield but preference for pasture is not affected by herbage allowance. J. Animal Sci. 92, 5175-5184. 
Motupalli, P. R., Rutter, S. M., Bleach, E. C. and Sinclair, L. A. 2013. Dairy heifer preference for being indoors or at pasture is affected by previous experience. In: Proceedings of the $47^{\text {th }}$ Congress of the International Society for Applied Ethology, Florianopolis, Brazil, 2-6 June 2013. Pp 114.

Munksgaard, L., Jensen, M.B., Pedersen, L.J., Hansen, S.W. and Matthews, L., 2005. Quantifying behavioural priorities-effects of time constraints on behaviour of dairy cows, Bos Taurus. Appl. Anim. Behav. Sci. 92, 3-14.

Nardone, A., Lacetera, N., Bernabucci, U. and Ronchi, B., 1997. Composition of colostrums from dairy heifers exposed to high temperatures during late pregnancy and the early postpartum period. J. Dairy Sci. 80, 838-844.

O’Driscoll, K., O’Brien, B., Gleeson, D. and Boyle, L., 2010. Milking frequency and nutritional level affect grazing behaviour of dairy cows: A case study. Appl. Anim. Behav. Sci. 122, 77-83.

Olmos, G., Boyle, L., Hanlon, A., Patton, J., Murphy, J.J. and Mee, J.F., 2009. Hoof disorders, locomotion ability and lying times of cubicle-housed compared to pasture-based dairy cows. Livest. Sci. 125, 199-207.

Overton, M.W., Sischo, W.M., Temple, G.D. and Moore, D.A., 2002. Using time-lapse video photography to assess dairy cattle lying behavior in a free-stall barn. J. Dairy Sci. 85, 2407-2413.

Peeler, E.J., Green, M.J., Fitzpatrick, J.L., Morgan, K.L. and Green, L.E., 2000. Risk factors associated with clinical mastitis in low somatic cell count British dairy herds. J. Dairy Sci. 83, 2464-2472.

Phillips, C.J.C. 1993. Cattle Behaviour. Ipswich: Farming Press.

Phillips, C.J.C. 2002. Cattle Behaviour and Welfare. 2nd edition. Oxford: Blackwell Science.

Phillips, C.J.C. and Morris, I.D., 2000. The locomotion of dairy cows on concrete floors that are dry, wet, or covered with a slurry of excreta. J. Dairy Sci. 83, 1767-1772.

Regula, G., Danuser, J., Spycher, B. and Wechsler, B. 2004. Health and welfare of dairy cows in different husbandry systems in Switzerland. Prev. Vet. Med. 66, 247-264. 
Ribeiro Filho, H.M.N., Delagarde, R. and Peyraud, J.L., 2005. Herbage intake and milk yield of dairy cows grazing perennial ryegrass swards or white clover/perennial ryegrass swards at lowand medium-herbage allowances. Anim. Feed Sci. and Tech. 119, 13-27.

Rutter, S.M. 2006. Diet preference for grass and legumes in free-ranging domestic sheep and cattle: current theory and future application. Appl. Anim. Behav. Sci. 97, 17-35.

Rutter, S.M., 2010. Review: Grazing preferences in sheep and cattle: Implications for production, the environment and animal welfare. Can. J. Anim Sci, 90, 285-293.

Rutter, S.M. 2012. A 'smart' future for ruminant livestock production? Cattle Practice, 20, 186-193.

Schreiner, D.A. and Ruegg, P.L., 2003. Relationship between udder and leg hygiene scores and subclinical mastitis. J. Dairy Sci. 86, 3460-3465.

Schütz, K.E., Cox, N.R. and Matthews, L.R. 2008. How important is shade to dairy cattle? Choice between shade or lying following different levels of lying deprivation. Appl. Anim. Behav. Sci. $114,307-318$.

Schütz, K.E., Rogers, A.R., Poulouin, Y.A., Cox, N.R. and Tucker, C.B., 2010. The amount of shade influences the behavior and physiology of dairy cattle. J. Dairy Sci. 93, 125-133.

Shabi, Z., Murphy, M.R. and Moallem, U., 2005. Within-day feeding behavior of lactating dairy cows measured using a real-time control system. J. Dairy Sci. 88, 1848-1854.

Somers, J.G.C.J., Frankena, K., Noordhuizen-Stassen, E.N. and Metz, J.H.M., 2005a. Risk factors for digital dermatitis in dairy cows kept in cubicle houses in The Netherlands. Prev. Vet. Med. $71,11-21$

Somers, J.G.C.J., Frankena, K., Noordhuizen-Stassen, E.N. and Metz, J.H.M. 2005b. Risk factors for interdigital dermatitis and heel erosion in dairy cows kept in cubicle houses in The Netherlands. Prev. Vet. Med. 71, 23-34.

Spörndly, E., and Wredle, E., 2004. Automatic milking and grazing - effects of distance to pasture and level of supplements on milk yield and cow behavior. J. Dairy Sci. 87, 1702-1712.

Sprecher, D.J., Hostetler, D.E. and Kaneene, J.B., 1997. A lameness scoring system that uses posture and gait to predict dairy cow reproductive performance. Theriogenology. 47, 1179-1187. 
St-Pierre, N.R., Cobanov, B. and Schnitkey, G., 2003. Economic losses from heat stress by US livestock industries. J. Dairy Sci. 86, Supplement 1, E52-E77.

Tapki, I. and Şahin, A., 2006. Comparison of the thermoregulatory behaviours of low and high producing dairy cows in a hot environment. Appl. Anim. Behav. Sci. 99, 1-11.

Telezhenko, E. and Bergsten, C., 2005. Influence of floor type on the locomotion of dairy cows. Appl. Anim. Behav. Sci. 93, 183-197.

Tolkamp, B.J., Haskell, M.J., Langford, F.M., Roberts, D.J. and Morgan, C.A., 2010. Are cows more likely to lie down the longer they stand? Appl. Anim. Behav. Sci. 124, 1-10.

Tucker, C.B., Rogers, A.R., Verkerk, G.A., Kendall, P.E., Webster, J.R. and Matthews, L.R., 2007. Effects of shelter and body condition on the behaviour and physiology of dairy cattle in winter. Appl. Anim. Behav. Sci. 105, 1-13.

Tucker, C.B. and Weary, D.M., 2004. Bedding on geotextile mattresses: how much is needed to improve cow comfort? J. Dairy Sci. 87, 2889-2895.

Tucker, C.B., Weary, D.M. and Fraser, D., 2003. Effects of three types of free-stall surfaces on preferences and stall usage by dairy cows. J. Dairy Sci. 86, 521-529.

Tucker, C.B., Weary, D.M. and Fraser, D., 2004b. Free-stall dimensions: effects on preference and stall usage. J. Dairy Sci. 87, 1208-1216.

Tucker, C.B., Weary, D.M., Rushen, J. and de Passillé, A.M., 2004a. Designing better environments for dairy cattle to rest. Adv. Dairy Tech. 16, 39-53.

Vandenheede, M., Nicks, B., Shehi, R., Canart, B., Dufrasne, I., Biston, R. and Lecomte, P. 1995. Use of a shelter by grazing fattening bulls: effect of climatic factors. Anim. Sci. 60, 81-85.

Vanegas, J., Overton, M., Berry, S.L. and Sischo, W.M., 2006. Effect of rubber flooring on claw health in lactating dairy cows housed in free-stall barns. J. Dairy Sci. 89, 4251-4258.

Vanhonacker, F., Verbeke, W., Van Poucke, E. and Tuyttens, F.A.M. 2008. Do citizens and farmers interpret the concept of farm animal welfare differently. Livest. Sci. 116, 126-136.

Vermunt, J.J. 2006. Reflections on prevention and control of bovine lameness in Australasian pasture-based systems. In: Proceedings of the 14th International Symposium and 6th Conference on lameness in Ruminants, Uruguay, 8-11 November 2006. pp 10-14. 
Walker, S.L., Smith, R.F., Routly, J.E., Jones, D.N., Morris, M.J. and Dobson, H., 2008. Lameness, activity time-budgets, and estrus expression in dairy cattle. J. Dairy Sci. 91, 4552-4559.

Washburn, S.P., White, S.L., Green Jr., J.T. and Benson, G.A., 2002. Reproduction, mastitis, and body condition of seasonally calved Holstein and Jersey cows in confinement or pasture systems. J. Dairy Sci. 85, 105-111.

Webster, J. 1987. Understanding the Dairy Cow. Oxford: BSP Professional Books

Webster, J. 1994. Animal Welfare: A Cool Eye towards Eden. Oxford: Blackwell Science.

Webster, J. 2005. Animal Welfare: Limping towards Eden. Oxford: Blackwell Publishing.

Webster, J. 2016. Animal Welfare: Freedoms, Dominions and "A Life Worth Living". Animals, 6, 35.

Wechsler, B., Schaub, J., Friedli, K. and Hauser, R. 2000. Behaviour and leg injuries in dairy cows kept in cubicle systems with staw bedding or soft lying mats. Appl. Anim. Behav. Sci. 69, 189197.

West, J.W. 2003. Effects of heat stress on production in dairy cows. J. Dairy Sci. 86, 2131-2144.

Wierenga, H.K. and Hopster, H., 1990. The significance of cubicles for the behaviour of dairy cows. Appl. Anim. Behav. Sci. 26, 309-337. 